\title{
ECLIPSE DE LA NEBULEUSE DU CRABE PAR LA COURONNE SOLAIRE
}

\author{
E. J. BLUM ET A. BOISCHOT \\ Observatoire de Meudon, Meudon (Seine-et-Oise), France
}

En 1957 et 1958 des observations de la nébuleuse du Crabe lors de son passage derrière la couronne solaire ont été effectuées sur $169 \mathrm{Mc} / \mathrm{s}$ à l'aide de l'interféromètre méridien à 32 antennes de Nançay [1, 2]. Cet appareil ayant un pouvoir séparateur de 3'.8 dans la direction est-ouest et un lobe principal tous les deux degrés, nous permet de distinguer le rayonnement de la radiosource même quand elle est très proche du soleil. Le flux maximum reçu lors du passage de la source non élargie atteignant 10 pour cent du flux donné par le soleil calme, la source sera très facile à distinguer sur les enregistrements.

En 1957 seulement deux enregistrements utilisables ont été obtenus pendant la période allant du 10 au 20 Juin. Les résultats en ont déjà été publiés [3].

En 1958, le soleil est resté calme pendant toute la période correspondante, excepté le 12, où une éruption, accompagnée d'une forte émission radio a eu lieu pendant les observations. - Les $13,15,17$, et 19 Juin, il est impossible de déduire des enregistrements des valeurs précises concernant la radiosource car celle-ci se trouve soit sur les flancs raides des lobes correspondant au soleil, soit sur les sommets de ces lobes, dont la forme varie sensiblement d'un jour à l'autre.

Nous avons donc de bonnes mesures les 11 et 13 Juin 1957 et les 11,14 , 16 , et 18 Juin 1958.

Le Tableau I donne les valeurs mesurées, $\alpha$ étant l'ascension droite de la nébuleuse, $\theta$ son diamètre apparent et $\emptyset$ sa densité de flux. $D$ est la distance entre le centre de la nébuleuse et le centre du disque photosphérique.

\section{ASCENSION DROITE}

La précision des mesures d'ascension droite de la nébuleuse au voisinage du soleil est inférieure à celle obtenue pour les radiosources éloignées du soleil [2]. Nous l'estimons $a+4^{\mathrm{s}}$ quand la source est très élargie et $\pm 2^{\mathrm{s}}$ quand son diamètre n'est pas modifié. Nous pouvons conclure des mesures qu'il n'y a pas de déplacement apparent de la radiosource supérieur à 30 secondes d'arc, quand elle passe derrière la couronne.

\section{DIAMETRE APPARENT}

Sur la Fig. 1 nous avons porté, en fonction de la distance $D$, les valeurs des diamètres mesurés en 1957 et 1958 (courbe $A$ ). La cohérence des résultats 


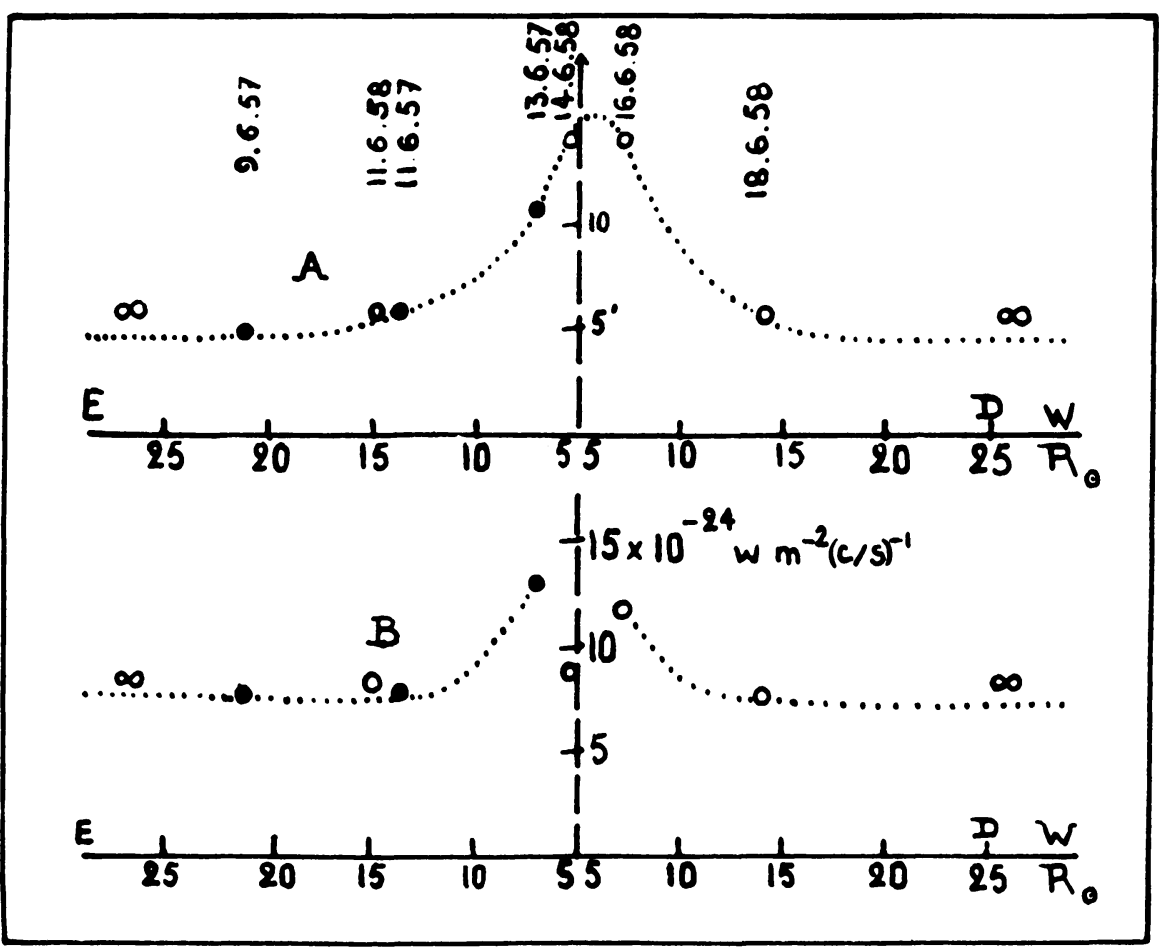

Fig. 1. Variations du diamètre apparent $\theta$ (courbe $A$ ) et de la densité de flux (courbe $B$ ) de la nébuleuse du Crabe en fonction de sa position par rapport au soleil.

obtenus montrent que la couronne n'a pas varié sensiblement d'une année à l'autre.

La courbe $A$ montre que le diamètre apparent de la nébuleuse du Crabe croit quand celle-ci s'approche du soleil. Cet effet se fait sentir à partir de $16 R_{\odot}$, comme le montrent les mesures des 11 Juin 1957, 11 Juin 1958, et 18 Juin 1958.

La valeur du diamètre atteint 15 minutes d'arc lorsque la nébuleuse est proche du soleil $\left(5 R_{\odot}\right)$. Les valeurs obtenues le 13 et le 16 semblent en outre montrer que l'augmentation de diamètre apparent est légèrement plus faible quand la nébuleuse se rapproche du soleil que lorsqu'elle s'en éloigne. Ceci peut d'ailleurs s'expliquer simplement par le fait que le 16 la position de la nébuleuse est plus proche du plan équatorial solaire que le 13, par suite de la valeur négative de l'angle de position du soleil.

\section{DENSITE DE FLUX}

Les mesures de densité de flux sont moins précises que celles des diamètres. Elles s'obtiennent en planimétrant le lobe enregistré et des erreurs importantes peuvent être faites si le niveau de base de ce lobe est mal déterminé. Les mesures des 13 et 16 Juin 1957 sont cependant très bonnes et l'erreur estimée est inférieure à 15 pour cent. 
La courbe $B$ donne les valeurs trouvées en fonction de la position de la nébuleuse par rapport au soleil et semble confirmer le fait déjà signalé [3] que l'intensité apparente totale de la radiosource augmente à l'approche du soleil. Bien que la mesure du 14 Juin 1958 soit moins précise, et qu'une diminution de la densité de flux, ce jour-là, soit moins certaine, il est intéressant de comparer la variation du flux trouvée avec les courbes obtenues par Link [4] qui calcule les modifications apparentes de la radiosource par suite de la réfraction par la couronne solaire. De toutes façons, il semble nécessaire de faire intervenir la réfraction, en plus de la diffusion, pour expliquer les phénomènes observés.

\section{TABLEAU I}

\begin{tabular}{|c|c|c|c|c|c|}
\hline \multicolumn{2}{|c|}{ Date } & $\frac{D}{R_{\odot}}$ & $\begin{array}{cc}\alpha & 1950 \\
05^{\mathrm{h}} & 31^{\mathrm{m}}\end{array}$ & $\stackrel{\theta}{\text { minutes d'arc }}$ & $10^{-26} \mathrm{wm}^{-2}(\mathrm{c} / \mathrm{s})^{-1}$ \\
\hline & 9 Juin & 21.3 & $32^{s} \pm 2^{s}$ & $4.6 \pm 0.1$ & 750 \\
\hline & 11 Juin & 13.8 & $31 \pm 2$ & $5.6 \pm 0.2$ & 750 \\
\hline & 13 Juin & 7.2 & $29 \pm 4$ & $10.7 \pm 0.5$ & 1290 \\
\hline \multirow[t]{5}{*}{1958} & 11 Juin & 15.0 & $31.5 \pm 2$ & $5.7 \pm 0.2$ & 810 \\
\hline & 14 Juin & 5.4 & $34.5 \pm 4$ & $14.1 \pm 1$ & 865 \\
\hline & 16 Juin & 7.1 & $30.5 \pm 4$ & $14.1 \pm 1$ & 1170 \\
\hline & 18 Juin & 13.9 & $32.5 \pm 2$ & $5.6 \pm 0.2$ & 750 \\
\hline & & & 31.5 & $4.6 \pm 0.1$ & 750 \\
\hline
\end{tabular}

\section{REFERENCES}

[1] Blum, E. J., Boischot, A., et Ginat, M. Ann. Astrophys. 20, 155, 1957.

[2] Boischot, A. Thèse, Paris, 1958 (à paraître dans Ann. Astrophys.).

[3] Blum, E. J., et Boischot, A. The Observatory, 77, 205, 1957.

[4] Link, F. Bull. Astr. Insts. Csl. 3, 6, 1952.

\section{Discussion}

Link: The increase in flux density observed by Boischot was predicted by the theory I gave in 1952 (Bull. Astr. Insts. Csl. 3, 6, 1952). It is a result of the differential refraction, which deforms the image of the Crab in the same way as the image of the sun is deformed at sunset. However, in the case of electronic refraction in the corona the deformation causes an increase in the surface area of the image, which causes-thanks to the invariance of the brightness-the increase in the flux density observed by Boischot. The increase, however, implies a refraction of 12 minutes of arc at a distance of 7 solar radii, which corresponds to an electron density of $5 \times 10^{5}$ electrons $/ \mathrm{cm}^{3}$, which is about ten times greater than according to optical measurements. Furthermore, the radial deviation of 12 minutes of arc implies a variation of minus or plus 25 seconds approximately in right ascension, while Boischot's measurements allow only about 3 seconds. Finally, the increase in diameter in a ratio of $1: 3$ found by Boischot is too great to be comparable with the increase of flux density. 
Hewish: I am interested by the increase of integrated brightness reported by Boischot. We find no evidence for this at $7.9 \mathrm{~m}$, where such effects might be more prominent. Do these results depend upon any assumption concerning the shape of the scattered distribution?

Denisse: This result does not depend on any assumption about the shape of the source. I think the theory of the phenomena has no bearing on this problem; we observe the same thing and do not get the same results. Both observations are related to one-dimensional scans of the source, and they should give the same results. Boischot finds no variation in position (to \pm 1 minute of arc) and an increase in amplitude on June 13 and 16 instead of a decrease. In my opinion the discrepancies stem from different interpretations of the data and need to be cleared up.

Vitkevich: According to Denisse's data, the flux density of the Crab nebula during the occultation increases, but refraction is absent. According to Slee's data, the flux density decreases. These results may be explained if we assume that there is refraction in the direction nearly perpendicular to the direction of measurement. It is possible that the large inhomogeneities in the outer corona cause such an effect; they may be the extended rays that are observed optically in the innermost parts of the corona.

Pawsey: In Sydney, O. B. Slee has taken observations of coronal occultations of the Crab nebula using the $85-\mathrm{Mc} / \mathrm{s}$ Mills cross. In 1956, 1957, and 1958 observations were made with the 3/4-degree fan beam of the east-west arm; in 1958 the 3/4-degree pencil beam of the full cross was also used. The fan-beam records consistently show a broadening and a reduction of peak amplitude of the response due to the Crab nebula, consistent with the order of scattering discussed previously. The pencil-beam records, however, are capable of showing details of structure which the fan-beam and interferometer techniques could not delineate. They show an interesting effect. On the day of closest approach, when the Crab lay near the solar axis, the response was greatly widened out and reduced in peak amplitude, but was roughly symmetrical. But, on the two days immediately preceding and succeeding this the response was even more distorted and showed two distinct peaks. This result must be due to effects of large scale irregularities in the corona in the vicinity of the pole. It illustrates also the complementary merits of pencilbeam and interferometer techniques: the pencil beam can more readily delineate the broad outlines, the interferometer can more simply detect a quite small amount of scattering. We expect that a full account of this work will be published in the Australian Journal of Physics.

Roberts: I would like to ask if it is possible from the occultation observations to infer the effect of irregularities on the emission of sources located in the corona near the plasma level-both the effects on the cone of emission and on the observed source size.

Hewish: The scattering of a point source on the sun can be estimated, but it depends upon an interpolation of the scattering data in the range from zero to 5 solar radii. 